Flash tale

Murmúrations:

Journal of

Transfórmative

Systemic

Practice

\title{
Escaping Bachelard's Dual Anthropology. Towards a New Post-corona Version of the Self
}

\author{
Karin Hannes, Mav 2020
}

Volume 3

Issue 1

Autumn 2020

Keywords:

place-based research,

Bachelard, COVID-19,

storytelling

Citation Link
The lockdown will continue for another four weeks, so I have heard on the radio this morning. Quarantine. I am out of my public zone. My social, methodological and theoretical innovation lab is somewhere 'out there', so is my staff. Their fieldwork has been put on hold, as physical contact for research and consultancy purposes is currently not allowed. I haven't heard back from them recently, other than during our weekly, joined virtual coffee breaks. The nature of my relationship with them feels quite different now. Our internet connection is stable, but I wonder what it might be like for colleagues working with fragile, vulnerable or deprived people. Would these professionals still have a presence in their clients lives? If so, what would it look like?

I am used to entering my lab around 9am. By 10am I would have had my first cup of coffee and greeted my students and colleagues. From then on, I am on a non-stop roller coaster of bodily and mental presence@work. One person enters my office, another group moves out. I am used to leaving around 6pm, after I have stuffed some 'homework' in my trolley; thoughts, ideas, scribbles, notes from a teleconference, a meeting, or an informal chat with a colleague, quotes I have written down. I seldom write anything substantial during office time or in my work place, nor do I develop any new ideas for projects or research work in there. In the lab it is my rational self that regulates my relationship with people, deals with things and events, takes and answers questions, critiques and conceptualises, reads, corrects and intervenes with the system level of the university. When I come home I am usually exhausted. The trolley I am pulling contains all sorts of stuff apart from the home work; ripples on the surface, ideas that I parked in the back of my head, unfinished business and emotional triggers that I have not been able to manage properly during day time. In my work environment every moment is counted for, interruptions are experienced as disturbing, meeting time is 'timed', which I find rather convenient as most of the content discussed at the meetings lacks the dynamic to inspire. 
Home is where no-one requires me to produce, deliver or consent against tight deadlines. Home is where I can hide away in the small corners of the house to read and write for pleasure. It is where I control the off and on button of my internet connection and consequently, the human and non-human noise level that I am willing to invite into the room or can tolerate. It is by the mercy of the corona lockdown and the disruption of my daily life pattern that I suddenly came to realise that I have been living Bachelard's (1972) double anthropology for too many years now. In these little corners of the house, I fold back to what Bachelard once identified as the day-dreaming nocturnal self, the one that wanders around solitarily in the relative silence of the home space where her subjectivity is protected. In normal times, it would only take over when the rational, diurnal self that socialises and works in the public sphere has come to a rest (Bachelard 2000[1936]). Yet here I am, at 11am, at our purple sofa in the corner of the living room, in the company of Butler's (2015) 'Notes towards a performative theory of assembly', reading for pleasure.

Butler's (2015) book is a series of papers in which she broadens her theory of performativity beyond speech acts that enact or produce that which is named. Her focus lies on concerted actions of the body. I slowly digest her point of view about embodied ways of coming together in solidarity meant to broaden our understanding of what public spaces of appearance are and how they are negotiated. Several images come to mind from the past couple of years; the yellow vest movement that began late 2018 in France, the school climate strike movement initiated by Greta Thunberg, the \#Me-too mass demonstrations in 2017, with millions of females appearing on the street to protest against sexual assault, the terrorist attacks in Paris, Brussels and Berlin that initiated several silent marches in the year 2016. In crisis situations, people tend to respond with a bodily presence. In the inability to do so under the lock down regulations, they are likely to invent other strategies to have their voice heard. While reading, my mind drifts away to the many collective forms of solidarity that have been initiated since the outbreak of the coronavirus; the rounds of applause and the white sheets hanging from the balconies of citizens, the cuddly toy bears behind the windows and in the gardens of my fellow villagers. They serve as a token of appreciation and respect for the work health care practitioners and employees working in the public sphere are doing during the COVID-19 crisis. I perceive them as an intelligent, creative response from those whose voices are not loud enough to be heard over the news and the internet [not to be confused with not worthy of getting any speech time at all]. These soft, fluffy toys on display do not speak, yet they are overwhelmingly loud in their collective visibility and difficult to neglect by those who hold the power over pen and paper.

So I pick up my pen, and start writing in the confusing moment of figuring out which self is actually in charge now, as under normal circumstances the intuitive 'nocturnal' one would only reveal itself between 9 and $12 \mathrm{pm}$. I am slightly distracted by the noise of my family members next door, but the very act of intentionally trying to mute my strong conceptualising 'diurnal self' late morning fills me with a sense of joy. I allow myself to dwell in the spontaneous images of fluffy toys and clean, soft, spotless white sheets that have entered my mind. My thoughts wander off in a multiplicity of different directions before the image of the cuddly bear behind the windows begins to challenge my current understanding of public versus private spheres, or the idea that there is something like a public political sphere 'out there', where speech manifests itself and bodies can claim the right to gather that opposes the private home sphere in which collective actions cannot possibly reside (Butler, 2011). The corona lockdown introduces the window of the villager's house as a threshold between private and public sphere, in response to the political impossibility to gather elsewhere during this pandemic. 
I ponder over the whole notion of Bachelard's dual anthropology again, the private and public dimension of my professional activities, while I listen to the endless stream of bleeps generated by the smartphone of my oldest son. I start longing for a cubbyhole in the living room where I can withdraw myself from the sound; solitude. One of my boy's friends virtually enters the living room. My second son opens his laptop, sits next to me and initiates a chat with one of his classmates about an assignment they are about to finish. Rhythm is accelerating in our little cocoon. I am almost tempted to ring one of my colleagues through business skype...; public sphere actor meets whom exactly in private? Then the postman rings twice and delivers a pre-ordered parcel. It contains a new pair of sneakers for my daughter. I ask her whether she is willing to try them on. She asks me whether I am willing to break out of her bedroom. In one of her moments of boredom inextricably linked to the corona lockdown situation, she reconfigured it as an escape room. Despite the buzz and fuzz of social media and internet entertainment, she now also knows solitude behind a window. I enter her live-action game willingly, solve her puzzles and I carefully read her clues. They open up a space of thought and imagery that is larger than what she has hidden in the room for me to discover. The distinction between my diurnal and nocturnal self suddenly becomes superfluous. While I am slowly working my way out of her room I find my intuitive, day-dreaming, imaginative part in perfect harmony with my rational problem solving capacity and I experience a comfortable unity of mind.

I reflect on the new work-life balance mantra recently adopted by my university. It encourages us to clearly distinguish between work/play time and work/leisure space, as if work should not be considered life, and our aspiration to live a pleasure-prone life does not require us to work hard from time to time. I envision a post-corona version of myself. It embraces Bachelard's 'pedagogy of reverie' (Chimisso, 2017, p. 193) yet opposes Bachelard's idea that one's imaginative nocturnal self usually is an obstacle in systematically investigating a way out of the complex, emerging societal problems we study in a research context. The reason why I feel so exhausted by the end of the day is probably because my university demands a particular type of presence. It does not shelter daydreaming, nor does it allow me to wander around in peace (Bachelard, 2014). Its windows are less of a threshold between public and private spaces than they are a guard against imaginative thought. There simply is no place to escape ${ }^{1}$.

\section{References}

Bachelard, Gaston. (2014). The poetics of space. Penguin Classics.

Bachelard, Gaston. (2000 [1936]). The Dialectic of Duration, with an Introduction by Cristina Chimisso. Manchester: Clinamen.

Bachelard, Gaston. (1972 [1953]). Le matérialisme rationnel. Paris: Presses Universitaires de France. Butler, Judith. (2011). Bodies in Alliance and the Politics of the Street. European Institute for Progressive Cultural Policies, 9.

\footnotetext{
${ }^{1}$ During the COVID-19 crisis, the author bought an abandoned shed in her own local village, developed a concept for a research-practice collaborative space somewhere in between the public and the private sphere and, implemented it in practice. The post corona version of herself is now hosted @ www.dorpsplein13.be
} 
Butler, Judith. (2015). Notes toward a performative theory of assembly. Harvard University Press.

Chimisso, Cristina. (2017). Gaston Bachelard's Places of the Imagination and Images of Space. In Place, Space and Hermeneutics (pp. 183-195). Springer, Cham.

\section{Author}

Karin Hannes is associate professor and coordinator of Research Group SoMeTHin'K (Social, Methodological and Theoretical Innovation / Kreative). She pushes towards the development of methods and models for positive change in society. She tests, evaluates, implements, and improves existing methods, techniques, models or d.a.t.a sets generated in fields such as urban development, social welfare, the public art, design and technology sector, community-based research practice and the global sustainable development area. Where necessary, she re-appropriates methods developed in other disciplines (art \& science) for use in the broad field of humanities, or develops her own innovative approach to respond to emerging social challenges, whilst remaining sensitive to quality control and empirical grounding. Her research perspective is multimodal, combining numerical, textual, sensory and/or arts-based research d.a.t.a to study complex social phenomena. She also develops theoretical frameworks as a basis for how such phenomena can be understood and organized.

Karin Hannes, KU Leuven, Faculty of Social Sciences, Parkstraat 45, Leuven, 3000, Belgium

E-mail: Karin.hannes@kuleuven.be

URL: https://www.kuleuven.be/wieiswie/en/person/00039686

\section{Citation}

Hannes, Karin (2020). Towards a New Post-corona Version of the Self. Escaping Bachelard's Dual Anthropology. Murmurations: Journal of Transformative Systemic Practice, 3, 1, 141-144. https://doi.org/10.28963/3.1.19 